\title{
Miranda
}

Revue pluridisciplinaire du monde anglophone /

Multidisciplinary peer-reviewed journal on the English-

speaking world

16 | 2018

L'expérimental dans la littérature et les arts

contemporains

\section{Simon Fletcher, Emma Purshouse and Dave Reeves (eds), The Poetry of the Black Country.}

Eric Doumerc

\section{(2) OpenEdition}

\section{Journals}

\section{Electronic version}

URL: http://journals.openedition.org/miranda/11458

DOI: 10.4000/miranda.11458

ISSN: 2108-6559

\section{Publisher}

Université Toulouse - Jean Jaurès

Electronic reference

Eric Doumerc, "Simon Fletcher, Emma Purshouse and Dave Reeves (eds), The Poetry of the Black Country. ", Miranda [Online], 16 | 2018, Online since 05 June 2018, connection on 16 February 2021. URL: http://journals.openedition.org/miranda/11458 ; DOI: https://doi.org/10.4000/miranda. 11458

This text was automatically generated on 16 February 2021

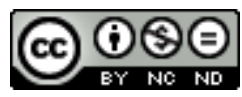

Miranda is licensed under a Creative Commons Attribution-NonCommercial-NoDerivatives 4.0 International License. 


\title{
Simon Fletcher, Emma Purshouse and Dave Reeves (eds), The Poetry of the Black Country.
}

\author{
Eric Doumerc
}

\section{REFERENCES}

Simon Fletcher, Emma Purshouse and Dave Reeves (eds), The Poetry of the Black Country

(Oswestry: Offa's Press, 2017), 70 p, ISBN 9780995522534.

1 The Poetry of the Black Country is a recent anthology of Black Country poetry edited by Simon Fletcher, Emma Purshouse, and Dave Reeves, three well-known poets from the Black Country. The Black Country is a former industrial area situated to the north-west of Birmingham and which used to specialise in the metal trades, iron and steel and coal mining as well. Other areas of activity included chain-making, lock-making and nailmaking. In the Victorian era, the Black Country was well-known for its industrial landscape, blast furnaces and coal mines. With the decline of heavy industry and coal mining in the 1970s, the area started to struggle economically and tried to adjust to the new economic situation.

Dave Reeves has been working as a freelance writer, performer and musician for over thirty years now. He sees himself as a performance poet, and performance is indeed the essence of what he does. He usually performs poetry while accompanying himself on the harmonica or the melodeon. His work has taken him to pubs, workingmen's clubs, literary and rock festivals, and many other places, and his performances never fail to enthral his audiences. From 1995 to 2008 he was editor of Raw Edge Magazine, a magazine which promoted new writing from the West Midlands. Dave Reeves is wellknown as a writer, poet and performer in the West Midlands, and, over the years, he has been involved in a number of community projects in rural or urban locations. 


$$
\text { Edinburgh Fringe, and is a member of a writing collective called "Poets, Prattlers and }
$$
Pandemonialists".

Simon Fletcher was born in Worcestershire, but lives in Shropshire. His 1994 collection, The Occasion of Love, was praised by Ted Hughes. He founded Offa's Press in 2010.

The anthology was the idea of the book's co-editor and manager of Offa's Press, Simon Fletcher who approached Emma Pushouse and Dave Reeves and asked them to edit the book. The Poetry of the Black Country is the latest in a series of anthologies from Offa's Press, which are concerned with a specific geographical area. The others are The Poetry of Shropshire and The Poetry of Staffordshire.

The main criterion for choosing the poets was simply that they should originate from, be now resident in, or be writing about the Black Country. Dave Reeves considers that, as "the area was originally built upon immigration, and the workforce was, historically, so fluid, [...] one in a sense can self-identify with the area and become a Black Country person, which many do, intrigued by the past of the area in which they find themselves" (recent email communication).

7 Dave Reeves can only name one previous anthology of Black Country poetry, and it was a very different kind of book. It is entitled Widening Circles (West Midlands Arts, 1976) and it features the five poets who were deemed at the time to be the best writing in the area: Roy Fisher, James William Jones, Peter Jones, Stephen Morris, and Bryan Walter.. of the five poets featured only one is still alive and he is now living in the South of France, working as a visual artist. Roy Fisher died in early 2017.

8 That said, the present anthology fits into or comes from a well-established tradition in English poetry: poems about a certain geographical area, poems about the working class or about the North. There is a strong tradition which consists in publishing local writers and there are many Writers' Groups all over the country. Regional presses are quite common. The main template for this kind of poetry would of course be Wordsworth and Coleridge's Lyrical Ballads (1798), with its ambition to write in the language of the common man, but, nearer to us, we could mention James William Jones' Black Country ballads, which became very popular in the 1970s (influenced by Robert Burns and the Dorset poet William Barnes), the Liverpool poets (Roger Mc Gough, Adrian Mitchell, and Adrian Henry), Tony Harrison, Philip Larkin, Roy Fisher, Thomas Hardy, and the Scottish poet Hugh Mc Diarmid.

9 Some of the poems featured in this anthology obviously fit the stereotype of Black Country poetry as a deeply nostalgic type of poetry about the past greatness of the region as a manufacturing hub, but other poems also deal with the theme of social divisions and explore language as a social indicator. Lastly, other poems seek to complicate the narrative and to transcend that limitation, thus opening the Black Country to other perspectives.

10 Some poems in the present anthology could be said to be deeply nostalgic about the industrial past. One of the best local poets, Roz Goddard, explores working-class life in a wonderfully evocative piece entitled "Careless Green". The poem is characterised by an elegiac tone: "the cut [a Black Country word for 'canal'] snaked grey/under the bridge" (29) and women were "hanging the wash over raggedy gardens" (29).

11 In "The Break-In", the persona wanders (or breaks) into the grounds of an old colliery and the past comes back to the surface. The grandfather's voice comes back from the 
past. Past and present mingle and the poem is about the continued relevance of the past in a post-industrial landscape.

In "Blast Furnace Lament", Peter Hill laments the decline of the iron and steel industry in Bilston. This piece is about the last Bilston blast furnace, Elizabeth, which was demolished in 1980.

Other poems are based on childhood recollections and explore the way language can enshrine and embody social divides. In "Waggin'", Christopher Adams uses typical Black Country expressions like "the cut" for a canal-"we'm down the cut" (7)-and tries to transcribe the sounds of Black Country dialect: "We ay ever caught anything/ but that doe bother us" (7).

14 In Liz Berry's "Homing", we learn that Black Country dialect has "consonants/you could lick the coal from" (9) and Natalie Burdett's "Boundaries" is clearly about the English class system which is enshrined in the geographical divisions which characterise the Black Country: the numerous references to the urban environment anchor the poem in a certain social reality.

There are also examples of concrete or shaped poetry in this anthology, like Liz Berry's "Bilston Enamels" (10) which looks at the links between art, history and place. Bilston was well-known for its enamels between 1760 and 1790. So were Wolverhampton and Wednesbury. This poem also looks at the importance of language and this type of ethnographic poetry often features dialect words to insist on the peculiarities of Black Country dialect. Notes are a feature of this type of poetry too.

16 The anthologists obviously tried to produce a publication that would challenge the idea of what a collection of Black Country verse should be about. They did that by including poems about the new faces that populate the Black Country these days. For instance, Stuart Haycox's "Two Thousand Feet above the Sea" is about the multi-ethnic nature of the Black Country today, with its East European workers and Kuli Kohli's "On the Buses" re-envisions the Black Country through Asian eyes and buses become metonyms for cultural diversity.

17 Roy McFarlane's "Tipton" is about growing up black in the Black Country. Roy McFarlane was born in Birmingham of Jamaican parentage and has lived in the Black Country, an industrial area to the north of Birmingham, most of his life. He is a former community worker and after working in many anti-racism projects in the 1990s, began to write and perform poetry around 2000 under the tutelage of the late Roi Kwabena, a Trinidadian poet and cultural activist who was then based in Birmingham. Roy's reputation as a poet and performer quickly grew and in 2009, he was appointed Starbucks Poet in Residence. In 2010-2011 he was Birmingham Poet Laureate.

18 In "Tipton" the poet voices his attachment to this small industrial town in the Black Country where he presently resides:

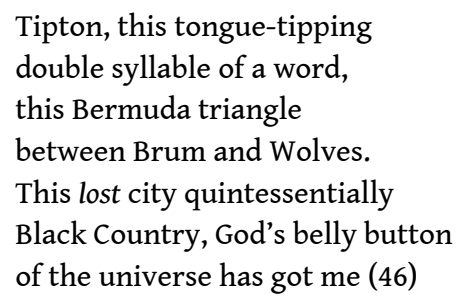

One of the outstanding pieces in this anthology is Emma Purshouse's "Flamingos in Dudley Zoo", a surrealist and cartoonesque piece about the impossibility of escaping, of 
casting off one's moorings and leaving the Black Country. The voices we hear are those of a flamingo and her grandson. This piece can thus be seen as a fable in which animals teach human beings a lesson, but this time in Black Country dialect:"You best talk proper, chick" (51). The flamingos are trapped in a zoo and cannot go anywhere because their wings have been clipped ("He doth know our wings am clipped", 51) and they may act as a metaphor for Black Country workers who cannot escape from their condition.

On the whole, this collection manages to achieve what the editors set out to do, that is to project an image of the Black Country which transcends its limitations and which goes beyond the usual stereotypes about the area. It is a refreshing and dynamic view associated with the future, not the past.

INDEX

Mots-clés: poésie du Black Country, West Midlands

Keywords: Black Country poetry, West Midlands

\section{AUTHORS}

\section{ERIC DOUMERC}

Maître de Conférences

Université de Toulouse-Jean Jaurès

doumerceric@neuf.fr 